\title{
Preparation and evaluation of functional foods in adjuvant arthritis
}

\author{
By S.Y. Al-Okbi* and D.A. Mohamed
}

\author{
Food Sciences and Nutrition department, National Research Centre, Cairo, Egypt \\ *Corresponding author: S_Y_alokbi@ hotmail.com
}

\section{RESUMEN}

Preparación y evaluación de alimentos funcionales en artritis adyuvante.

La artritis adyuvante es un modelo utilizado en animales y se caracteriza por ser muy parecida a la artritis reumatoide en humanos. Se trata de un modelo de trabajo utilizado con éxito para estudiar nuevos agentes anti-inflamatorios. En estudios previos (animales y clínica) hemos demostrado que el aceite de onagra, el aceite de pescado y los extractos metanólicos de semillas de fenogreco o alholva y de dátiles tienen actividad anti-inflamatoria y que el extracto metanólico de dátiles tiene efecto antioxidante. Basado en estos estudios, el objetivo del presente trabajo consistió en preparar alimentos funcionales con siete fracciones bioactivas por separado y conjuntamente y evaluarlas en artritis adyuvante en ratas, estudiar la estabilidad de los principios bioactivos y evaluar sus propiedades sensoriales. Los parámetros bioquímicas estudiados fueron la velocidad de sedimentación globular, la enzima superóxido dismutasa eritrocitaria, la glutatión peroxidasa, cobre plasmático, y la zinc interleucina-2. Los parámetros nutricionales, incluyendo ganancia de peso corporal, la ingesta de alimentos y la relación de eficiencia alimentaria se han seguido durante la ingesta de los alimentos funcionales. Los ingredientes bioactivos evaluados fueron el contenido de fenoles totales y ácidos grasos. Los resultados mostraron una mejoría de los parámetros bioquímicos, aumento de peso corporal y la relación de eficiencia alimentaria en las ratas artríticas que se alimentaron con los diferentes grados de alimentos funcionales. Todos los alimentos funcionales preparados fueron aceptables sensorialmente. Los ingredientes activos mostraron estabilidad durante el almacenamiento. Como conclusión, todos los alimentos funcionales probados mostraron una prometedora actividad anti-inflamatoria y fueron aceptables sensorialmente, siendo recomendable su uso como suplementos dietéticos por su potencial beneficio en pacientes con artritis reumatoide.

PALABRAS CLAVE: Aceite de onagra - Aceite de pescado - Ácidos grasos - Alimentos funcionales - Alholva Artritis adyuvante - Contenido fenólico - Dátiles - Fenogreco - Parámetros bioquímicos - Parámetros nutricionales - Ratas.

\section{SUMMARY}

Preparation and evaluation of functional foods in adjuvant arthritis.

Adjuvant arthritis is an animal model that closely resembles rheumatoid arthritis in humans. It is a successful working model used to study new anti-inflammatory agents. In previous studies (animal and clinical) we have shown that evening primrose oil, fish oil and the methanol extract of date fruits and fenugreek seeds have anti-inflammatory activity and that the methanol extract of dates has an antioxidant effect. Based on these studies, the aim of the present study was to prepare 7 functional foods containing such bioactive fractions separately or in combination and to evaluate them in adjuvant arthritis in rats, study the stability of bioactive ingredients and evaluate their sensory properties. The studied biochemical parameters were erythrocyte sedimentation rate, erythrocyte superoxide dismutase, glutathione peroxidase and plasma copper, zinc and interlukin 2. Nutritional parameters, including body weight gain, food intake and food efficiency ratio were monitored during the feeding of the functional foods. The bioactive ingredients assessed were total phenolic contents and fatty acids. The results showed improvement in the biochemical parameters, body weight gain and food efficiency ratio of arthritic rats fed on the functional foods with different degrees. All the prepared functional foods were sensory accepted. The active ingredients showed stability during storage. In conclusion, all the tested functional foods showed promising antiinflammatory activity and were determined to be acceptable through sensory evaluation which means that their potential beneficial use as dietary supplements in rheumatoid arthritis patients may be recommended.

KEY-WORDS: Adjuvant arthritis - Functional foods - Fenugreek - Date - Primrose oil - Fish oil - Phenolic content - Fatty acid - Biochemical parameters - Nutritional parameters - Rats.

\section{INTRODUCTION}

Rheumatoid arthritis (RA) is a systemic chronic inflammatory disease characterized by symmetric, erosive and chronic synovitis, especially of the minor joints where patients suffer pain and stiffness. (Brenol et al., 2007). It affects about $1 \%$ of the world population. Elevated oxidative stress in rheumatoid arthritis, due to impaired antioxidant systems caused by reactive oxygen species, might have an essential role in the etiology of the disease (Kalpakcioglu and Senel, 2008). Reactive oxygen species have been implicated as mediators of tissue damage in patients (Winyard et al., 2011). In a previous study we have proved that the methanol extract of dates has antioxidant activity in-vitro (Mohamed and Al-Okbi, 2005) and antiinflammatory and antioxidant activity in rats with adjuvant arthritis (Mohamed and Al-Okbi, 2004). Previously we have also shown that the methanol extract of fenugreek has anti-inflammatory activity 
in both acute and chronic inflammation (Ammar et al., 1997; Al-Okbi et al. 1998). Both fenugreek and date extracts were also proved to be very safe (Al-Okbi et al., 1999; Mohamed and Al-Okbi, 2004). Primrose oil and fish oil were reported to possess anti-inflammatory activity inpatients with rheumatoid arthritis (Al-Okbi et al., 2000) which may be due to the presence of specific polyunsaturated fatty acids [gamma-linolenic acid in the case of primrose oil and eicosapentaenoic acid (EPA) and decosahexaenoic acid (DHA) in the case of fish oil]. Therefore, it is of interest to make use of these functional food ingredients to produce functional foods for chronic inflammatory diseases including rheumatoid arthritis.

The aim of the present study was to prepare functional foods that may have beneficial effects on rheumatoid arthritis and to evaluate such foods in rats with adjuvant arthritis. The foods were subjected to sensory evaluation. The aim included studying the stability of the functional food ingredients in the prepared foods.

\section{MATERIALS AND METHODS}

\subsection{Materials}

Fresh date palm fruits, Phoenix dactylifera L. Family Palmae (Zaghlool), and fenugreek seeds (Trigonella foenum graecum L. Family Leguminose) were purchased from an Egyptian market. Evening primrose oil and fish oil were obtained from Sigma, USA.

Sprague Dawley male rats of $154.8 \mathrm{~g}$ average body weight were used in this study. The animals were obtained from Central Animal House, National Research Centre, Cairo, Egypt. The animals were kept individually in stainless steel cages; water and food were given ad-libitum. Freund's complete adjuvant (Sigma, USA) was used for the induction of adjuvant arthritis in rats.

\subsection{Methods}

\subsubsection{Preparation of extracts}

The date fruits were washed, seeds were separated and the edible portion was dried in a hot air oven at $40^{\circ} \mathrm{C}$. The dried fruit was reduced into coarse powder. Fenugreek seeds were washed, dried and ground into coarse powder form. The previously prepared date fruits and fenugreek seeds were separately placed in a continuous extraction apparatus using petroleum ether followed by methyl alcohol. The methanol was completely removed from the extracts by evaporation under reduced pressure.

\subsubsection{Preparation of functional foods}

Fresh date palm fruits were washed and the seed were separated. The edible portion of the date fruit was cut into small pieces and boiled in tap water. Then the solution was filtered and the pellets were kept in a refrigerator at $4^{\circ} \mathrm{C}$. The solution was boiled with sugar and citric acid. The pellets were added to the sugary solution and kept for $12 \mathrm{~h}$ for balance in the solution, then it was completely cooked, and sodium benzoate was added (0.025\%) as a preservative. The jam was divided into 7 parts and kept in glass jars. After cooling, the functional food ingredients (extract of date or fenugreek seed or both in combination, evening primrose oil alone or with date extract, fish oil alone or mixed with date extract) were added to the jam jars separately and then each type of jam was finely ground and homogenously mixed using an electric mixer. These mixtures gave 7 different functional foods. A jam without any treatment was used as the control.

\subsubsection{Sensory evaluation of functional food}

The prepared jam samples were subjected to a sensory analysis with 10 panelists. Each panelist was served a control jam sample along with the test samples and was asked to assign a score on a tenpoint scale for appearance, color, taste and overall acceptability. A sensory score of 5 or above was deemed acceptable, and a sensory score below 5 was considered unacceptable.

\subsubsection{Studying the stability of functional food ingredients in the prepared jam}

\subsubsection{Determination of total phenolic contents in the functional foods}

The total phenolic contents in the jam containing date extract, fenugreek extract or a combination of both were determined (freshly and after storage in the refrigerator for 2 months) using a modified FolinCiocalteu colorimetric method (Singleton et al., 1999).

\subsubsection{Determination of fatty acid profiles in jam containing evening primrose oil, fish oil separately or in combination with date extract according to AOAC (2000)}

Five grams of each prepared jam (fresh and after 2 months storage at $4^{\circ} \mathrm{C}$ ) were saponified by refluxing with $10 \%$ alcoholic potassium hydroxide, the unsaponifiable matter was extracted with ether and evaporated to dryness. The aqueous mother liquor was acidified with $10 \%$ hydrochloric acid and the liberated fatty acids were extracted with ether. Ether was evaporated and the residue was kept for studying fatty acids. The fatty acid fraction was subjected to methylation and analysis by GLC of the methyl ester adopting the following conditions: Stationary phase, $10 \%$ diethylene glycosuccinate packed column; oven temperature, $170^{\circ} \mathrm{C}$; detector temperature, $300^{\circ} \mathrm{C}$; injector temperature, $250^{\circ} \mathrm{C}$; Carrier gas, $\mathrm{N}_{2}$; flow-rate, $30 \mathrm{~mL} \mathrm{~min}^{-1}$; air flow-rate, $350 \mathrm{~mL} \mathrm{~min}^{-1} ; \mathrm{H}_{2}$ flow-rate, $350 \mathrm{~mL} \mathrm{~min}^{-1}$; detector, FID; chart speed, $2 \mathrm{~cm} \mathrm{~min}^{-1}$. Identification of the fatty acid methyl ester was carried out by direct comparison of the retention times of each of the 
separated compounds with authentic samples of the fatty acid methyl esters analyzed under the same conditions. Quantification was based on peak area integration.

\subsubsection{Preparation of experimental diets}

Different diets containing the different jams were prepared to feed rats throughout the experimental work (table 1). The constituents of the basal balanced diet were similar to those reported by AlOkbi et al. (2010) with minor modifications where sucrose in the previous work was replaced by jam in the present research.

\subsubsection{Design of experimental work}

Fifty-four rats were divided into 9 groups, each comprising six rats. The rats in each of the seven test groups were fed a balanced diet containing the different functional foods (Jam) separately. The other two groups served as control (one group as control normal and the second as control arthritic rats). The control normal and arthritic rats were fed a balanced diet containing the control jam. After a week from the beginning of the experiment, arthritis was induced in all the rats (except the control normal group) through subcutaneous injection of Freund's complete adjuvant into the sub-plantar region of the right hind-foot paw (Singh et al. 1992). The rats were kept on the different diets throughout the experiment. Paw thickness was measured before the induction of arthritis and twice weekly using a caliper. The experiment lasted 28 days from the beginning or 21 days from the injection. At the end of experiment, the increase in the thickness of the injected foot of the rats of the test groups was compared with that of the control arthritic rats. During the experiment, body weight and food intake were recorded twice weekly. At the end of the experiment total food intake, body weight gain and food efficiency ratio were calculated. After the experimental period had elapsed, the rats fasted for 14-16 hr. Blood samples were withdrawn and divided into three parts. One was mixed with trisodium citrate (109 mmol $\mathrm{L}^{-1}$ ) for the determination of the erythrocyte sedimentation rate (ESR) (Westergren, 1921). The second part of the blood was mixed with heparin for the determination of glutathione peroxidase (Paglia and Valentine, 1967). The third part of the blood was mixed with heparin, centrifuged and plasma was separated for the determination of plasma copper (Abe et al. 1989) and zinc (Homster \& Zak, 1985) by colorimetric methods. Plasma interlukin $2\left(\mathrm{IL}_{2}\right)$ was assessed using ELISA techniques (Euroclone Elisa Kit, UK). For erythrocyte superoxide dismutase determination (Roth and Gilgert 1984), $0.9 \% \mathrm{NaCl}$ was added to the red cell layer of the centrifugate, the red cells were centrifuged, washed three times and stored in a plastic tube at $-20^{\circ} \mathrm{C}$ until analysis.

Institutional and national guides for the care and use of laboratory animals were followed according to the Medical Research Ethics Committee for animal care and use, National Research Centre, Cairo, Egypt.

Statistical analysis. The results of the animal experiment were expressed as the mean \pm SE and the significance of the data was assessed by the Student's t-test. The results of the sensory evaluation were analyzed statistically using oneway analysis of variance ANOVA followed by a Duncan's test: $p<0.05$ was used as the criterion for statistical significance.

\section{RESULTS}

\subsection{Sensory evaluation of jam samples}

The control and the test jam samples containing the functional ingredients were sensory evaluated; the results are shown in table 2 . No significant differences were observed among the samples. All sensory parameters scored more than 8 out of 10 which are considered to be very good scores.

Table 1

Composition of different diets used in the experiment $\left({\left.\mathrm{g} 100 \mathrm{~g}^{-1}\right)}^{-1}\right.$

\begin{tabular}{lcccccccc}
\hline Ingredients & $\begin{array}{c}\text { Control } \\
\text { jam } \\
\text { diet }\end{array}$ & $\begin{array}{c}\text { Date } \\
\text { Extract } \\
\text { diet }\end{array}$ & $\begin{array}{c}\text { Fenugreek } \\
\text { extract } \\
\text { diet }\end{array}$ & $\begin{array}{c}\text { Date } \\
\text { \& fenugreek } \\
\text { extracts } \\
\text { diet }\end{array}$ & $\begin{array}{c}\text { Fish oil } \\
\text { diet }\end{array}$ & $\begin{array}{c}\text { Fish oil } \\
\text { \& date } \\
\text { extract diet }\end{array}$ & $\begin{array}{c}\text { Primrose } \\
\text { oil diet }\end{array}$ & $\begin{array}{c}\text { Primrose oil } \\
\text { \& date } \\
\text { extract diet }\end{array}$ \\
\hline${ }^{*}$ Casein & 11.9 & 11.9 & 11.9 & 11.9 & 11.9 & 11.9 & 11.9 & 11.9 \\
Corn oil & 10 & 10 & 10 & 10 & 10 & 10 & 10 & 10 \\
Sucrose & - & - & - & - & - & - & - & - \\
Starch & 45.6 & 45.6 & 45.6 & 45.6 & 45.6 & 45.6 & 45.6 & 45.6 \\
Jam & 23 & 23 & 23 & 23 & 23 & 23 & 23 & 23 \\
Cellulose & 5 & 5 & 5 & 5 & 5 & 5 & 5 & 5 \\
Salt mix. & 3.5 & 3.5 & 3.5 & 3.5 & 3.5 & 3.5 & 3.5 & 3.5 \\
Vit. Mix. & 1 & 1 & 1 & 1 & 1 & 1 & 1 & 1 \\
\hline
\end{tabular}

*11.9 g. casein contain $10 \mathrm{~g}$. protein. 
Table 2

Sensory evaluation of different jam samples

\begin{tabular}{|c|c|c|c|c|}
\hline Jam samples & Appearance & Color & Taste & Overall acceptability \\
\hline Control & $8.7 \pm 0.579$ & $9.3 \pm 0.605$ & $8.9 \pm 0.715$ & $8.8 \pm 0.682$ \\
\hline Date extract & $8.2 \pm 0.542$ & $9.2 \pm 0.582$ & $8.4 \pm 0.632$ & $8.6 \pm 0.531$ \\
\hline Fenugreek extract & $8.3 \pm 0.435$ & $9.0 \pm 0.469$ & $8.5 \pm 0.706$ & $8.5 \pm 0.385$ \\
\hline Date + fenugreek extracts & $8.3 \pm 0.623$ & $9.2 \pm 0.526$ & $8.6 \pm 0.541$ & $8.4 \pm 0.582$ \\
\hline Fish oil & $8.2 \pm 0.585$ & $9.2 \pm 0.611$ & $8.3 \pm 0.582$ & $8.2 \pm 0.625$ \\
\hline Date extract + fish oil & $8.2 \pm 0.605$ & $9.1 \pm 0.591$ & $8.2 \pm 0.622$ & $8.4 \pm 0.458$ \\
\hline Primrose oil & $8.3 \pm 0.592$ & $9.1 \pm 0.612$ & $8.4 \pm 0.483$ & $8.1 \pm 0.496$ \\
\hline Date extract + primrose oil & $8.3 \pm 0.618$ & $8.9 \pm 0.579$ & $8.1 \pm 0.508$ & $8.3 \pm 0.508$ \\
\hline
\end{tabular}

No significant differences were noticed among different sensory attributes of different jam samples.

\subsection{Studying the stability of functional food}

\subsubsection{Total phenolic contents}

The contents of phenolic compounds are present in table 3. The contents of total phenolics in the prepared functional foods ranged from 14.9 to 16.6 $\mathrm{mg}$ of gallic acid equivalents $\mathrm{g}^{-1}$ dry weight. The jam containing the methanol extract of fenugreek seeds had the highest content of total phenolic (16.6), while the jam containing the methanol extract of both date fruits and fenugreek seeds had the lowest level (14.9). Storage for 2 month at $4^{\circ} \mathrm{C}$ produced only minor changes in total phenolic contents. Therefore, we can conclude that the prepared functional food is stable when stored at $4^{\circ} \mathrm{C}$.

\subsubsection{Investigation of fatty acids of the prepared functional food}

The fatty acid profiles of jams that contains primrose oil alone or with date extract, fish oil alone or mixed with date extract (fresh or after 2 month of storage in the refrigerator) were analyzed by GLC. The results are shown in table 4 . It can be noticed that the jam containing either fish oil or primrose oil contains palmitic and oleic acids. Primrose contains stearic, linoleic and $12 \%$ gamma-linolenic acid. Fish oil contains myristic acid, linolenic acid, EPA and DHA.

Table 3

Total phenolic content of the different prepared jams

\begin{tabular}{lcc}
\hline \multirow{2}{*}{ Jam samples } & \multicolumn{2}{c}{$\begin{array}{c}\text { Total phenolic } \\
\text { (mg gallic acid equivalent } \mathbf{~}^{-1} \\
\text { dry weight) }\end{array}$} \\
\cline { 2 - 3 } & Initial & After 2 months \\
\hline Date extract & 15.6 & 15.5 \\
$\begin{array}{l}\text { Fenugreek } \\
\text { extract }\end{array}$ & 16.6 & 16.4 \\
$\begin{array}{l}\text { Date \& } \\
\text { Fenugreek } \\
\text { extracts }\end{array}$ & 14.9 & 14.8 \\
\hline
\end{tabular}

Storage of the prepared functional food for 2 month at $4^{\circ} \mathrm{C}$ induced minor changes in the fatty acid levels of jams containing primrose oil or fish oil alone. It was observed that added date extract acted as antioxidant and prevented changes in fatty acid contents.

\subsection{Effect of the prepared functional food on adjuvant arthritis}

The thickness of the injected foot paw during the experimental period is represented in figure 1. In the control arthritic rats, treatment with Freund's complete adjuvant (on the eighth day of the experiment) produced an inflammation which reached its maximum after 4 days, thereafter; the swelling slowly subsided until the elapse of sixteen days and remained almost steady until the twenty-first day after injection, which is the last day of the experiment. It was noticed that the functional food produced a marked reduction in the hind paw inflammation throughout the experiment in the different test groups.

The thickness of inflammation in the control arthritic rats at the end of the experiment compared with that of rats given the different jams is present in table 5. It was noticed that the functional food suppressed the swelling in the foot significantly $(p<$ 0.001 ), the reduction in swelling ranges from $48 \%$ to $62 \%$, which was superior in the case of jam containing fish oil with date extract.

\subsection{Biochemical parameters of arthritic rats}

The results of biochemical parameters of the different experimental groups are shown in table 6 . It was noticed that ESR was significantly higher in the arthritic control rats compared with the normal control. Erythrocyte superoxide dismutase activity was significantly higher in arthritic control rats than in normal rats $(p<0.001)$, while glutathione peroxidase activity was virtually the same in the arthritic control and normal rats. In the control arthritic rats, plasma zinc was significantly lower while plasma copper was significantly higher than the normal control $(p<0.001)$. The plasma level of IL2 increased significantly in the arthritic control compared with the normal control $(p<0.001)$. The 
Table 4

Fatty acids of the prepared jams as percentage of total fatty acids

\begin{tabular}{lcccccccc}
\hline \multirow{2}{*}{ Fatty acids } & \multicolumn{2}{c}{ Fish oil jam } & \multicolumn{2}{c}{$\begin{array}{c}\text { Fish oil \& Date } \\
\text { ext. jam }\end{array}$} & \multicolumn{2}{c}{ Primrose oil jam } & \multicolumn{2}{c}{$\begin{array}{c}\text { Primrose oil \& Date } \\
\text { ext. jam }\end{array}$} \\
\cline { 2 - 9 } & Initial & $\mathbf{2 ~ M}$ & Initial & $\mathbf{2} \mathbf{~ M}$ & Initial & $\mathbf{2} \mathbf{~ M}$ & Initial & 2 M \\
\hline Myristic & 12.7 & 13.0 & 12.7 & 12.7 & - & - & - & - \\
Palmitic & 43.3 & 43.8 & 43.3 & 43.3 & 9.1 & 9.3 & 9.1 & 9.1 \\
Stearic & - & - & - & - & 1.3 & 1.5 & 1.3 & 1.3 \\
Oleic & 19.5 & 19.8 & 19.5 & 19.5 & 12 & 12.6 & 12 & 12 \\
Linoleic & - & - & - & - & 63.2 & 62.5 & 63.2 & 63.2 \\
Gamma-linolenic & - & - & - & - & 12.0 & 11.8 & 12.0 & 12.0 \\
Linolenic & 1.5 & 1.2 & 1.5 & 1.5 & - & - & - & - \\
EPA & 14.0 & 13.8 & 14.0 & 14.0 & - & - & - & - \\
DHA & 5.2 & 5.0 & 5.2 & 5.2 & - & - & -
\end{tabular}

erythrocyte sedimentation rate and the erythrocyte superoxide dismutase activity of the arthritic rats decreased significantly in groups fed on balanced diets containing different functional foods but was still higher than the normal control. Plasma copper was reduced while plasma zinc increased significantly with variable degrees in arthritic rats fed the different functional foods compared to the arthritic control. The plasma level of IL2 was reduced significantly in arthritic rats fed the different functional foods compared to the arthritic control.

The results of nutritional parameters (Table 7), showed that body weight gain and food efficiency ratio decreased significantly in the control rats with adjuvant arthritis compared to the normal control. Feeding arthritic rats balanced diets containing the different functional foods produced an increase in body weight gain but it was only significant in groups fed the diet containing a combination of fenugreek and date extract $(p<0.010)$ and the diet of fish oil with date extract. Food efficiency increased significantly when rats fed the diets containing fenugreek with date extract, primrose oil in combination with date extract or fish oil with date extract.

\section{DISCUSSION}

Adjuvant arthritis is an animal model that closely resembles RA in humans and the biochemical

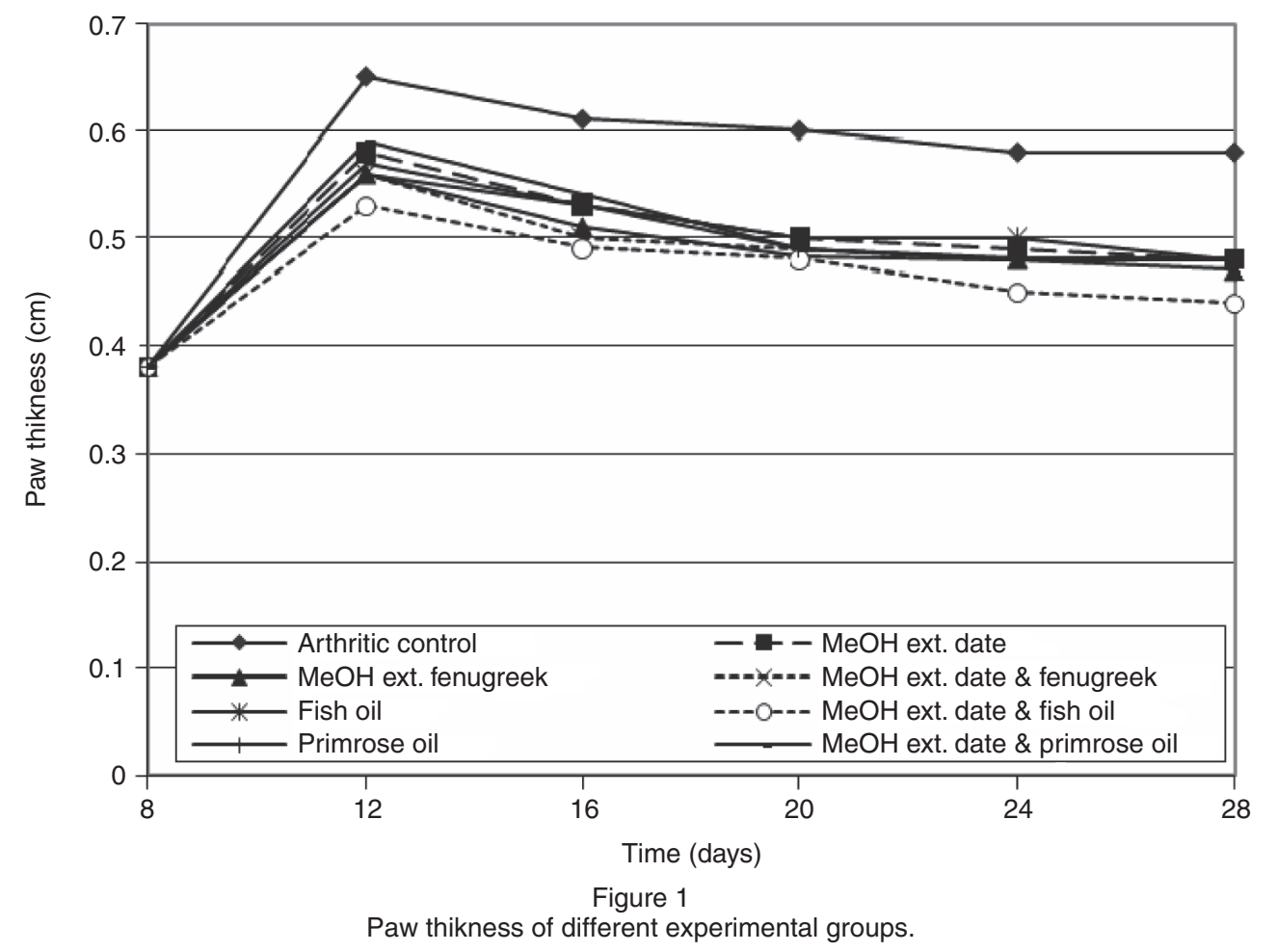


Table 5

Thickness of inflammation in cm (after 21 days of adjuvant arthritis induction) of arthritic rats given different functional foods

\begin{tabular}{lcc}
\hline \multicolumn{1}{c}{ Groups } & Mean \pm SE & $\begin{array}{c}\text { \% Inhibition of } \\
\text { inflammation }\end{array}$ \\
\hline Arthritic control & $0.21 \pm 0.015$ & - \\
Jam containing date extract & $0.1^{*} \pm 0.013$ & 52 \\
Jam containing fenugreek extract & $0.092^{*} \pm 0.015$ & 56 \\
Jam containing both date and fenugreek extract & $0.1^{*} \pm 0.013$ & 52 \\
Jam contain fish oil & $0.11^{*} \pm 0.024$ & 48 \\
Jam contain fish oil and date extract & $0.08^{*} \pm 0.011$ & 62 \\
Jam containing primrose oil & $00.1^{*} \pm 0.018$ & 52 \\
Jam containing primrose oil and date extract & $0.1^{*} \pm 0.0$ & 52 \\
\hline
\end{tabular}

Values significantly differ from the control: * $p<0.001$

changes and biomarkers in both are similar. In control adjuvant arthritis animals the elevated ESR, an inflammatory biomarker, showed in the present study agreed with other previous research (Ratheesh et al. 2009). ESR has been reported to be an excellent index for assessing the therapeutic effect of anti-inflammatory agents (Arvidsoon et al.,
1998). The high activity of erythrocyte superoxide dismutase in control adjuvant arthritis that has been noticed in the present study agreed with the results of Tuncer et al. (1999) but not with those of Kiziltunc et al. (1998). Increased oxidative stress in rheumatoid arthritis may lead to compensatory changes in the levels of some antioxidants like

Table 6

Biochemical parameters of different experimental groups

\begin{tabular}{|c|c|c|c|c|c|c|c|c|c|c|}
\hline & & $\begin{array}{l}\text { Normal } \\
\text { Control }\end{array}$ & $\begin{array}{l}\text { Arthritic } \\
\text { Control }\end{array}$ & $\begin{array}{l}\text { Date } \\
\text { extract }\end{array}$ & Fish oil & $\begin{array}{c}\text { Fish oil \& } \\
\text { Date extract }\end{array}$ & $\begin{array}{c}\text { Primrose } \\
\text { oil }\end{array}$ & $\begin{array}{l}\text { Primrose oil } \\
\text { \& Date extracts }\end{array}$ & $\begin{array}{c}\text { Fenugreek } \\
\text { extract }\end{array}$ & $\begin{array}{c}\text { Date \& } \\
\text { Fenugreek } \\
\text { extracts }\end{array}$ \\
\hline \multirow[t]{3}{*}{$\operatorname{ESR}\left(\mathrm{mm} \mathrm{h}^{-1}\right)$} & Mean & 1.3 & $3.7 \bullet$ & $2.5^{\star \star \star}$ & $2.2^{\star \star \star \star}$ & $2.2^{\star \star \star}$ & $2.3^{\star \star \star}$ & $2.2^{\star \star \star}$ & $2.3^{\star \star \star *}$ & $2.2^{* \star *}$ \\
\hline & $\pm S E$ & 0.192 & 0.192 & 0.204 & 0.154 & 0.152 & 0.192 & 0.152 & 0.192 & 0.152 \\
\hline & \%Change & - & +118 & -32 & -41 & -41 & -38 & -41 & -38 & -41 \\
\hline \multirow[t]{3}{*}{$\mathrm{Cu}\left(\mu \mathrm{g} \mathrm{dl}^{-1}\right)$} & Mean & 81.7 & $145.2 \bullet$ & $119.2^{\star \star}$ & $113^{\star \star \star}$ & $113.5^{\star \star \star}$ & $117.5^{\star \star \star}$ & $115.5^{\star \star \star}$ & $116.2^{\star \star \star}$ & $115.3^{\star \star \star}$ \\
\hline & $\pm S E$ & 1.774 & 3.846 & 5.324 & 3.872 & 3.732 & 5.862 & 4.207 & 2.639 & 2.805 \\
\hline & $\%$ Change & - & +78 & -18 & -22 & -22 & -19 & -20 & -20 & -21 \\
\hline \multirow[t]{4}{*}{$\mathrm{Zn}\left(\mu \mathrm{g} \mathrm{dl^{-1 }}\right)$} & Mean & 74.7 & $44 \bullet$ & $62^{* \star \star}$ & $68.2^{\star \star \star}$ & $68.5^{\star \star \star}$ & $64.3^{\star * *}$ & $66.3^{* * *}$ & $66.5^{\star \star \star}$ & $67.8^{* * *}$ \\
\hline & $\pm S E$ & 1.880 & 1.649 & 2.013 & 2.586 & 2.643 & 2.219 & 1.503 & 1.628 & 2.385 \\
\hline & $\%$ Change & - & -41 & +41 & +55 & +56 & +46 & +51 & +51 & +54 \\
\hline & Mean & 156.3 & 156.7 & 159.3 & $162.2^{*}$ & $163.2^{\star *}$ & 159.7 & 160.3 & 160 & 161.2 \\
\hline \multirow[t]{2}{*}{ GPx $\left(\mathrm{u} \mathrm{g}^{-1} \mathrm{Hb}\right)$} & $\pm S E$ & 1.677 & 1.239 & 1.521 & 2.019 & 1.362 & 1.362 & 1.122 & 1.545 & 2.073 \\
\hline & $\%$ Change & - & & +2 & +4 & +4 & +2 & +2 & +2 & +3 \\
\hline \multirow[t]{3}{*}{$\operatorname{SOD}\left(\mathrm{u} \mathrm{g}^{-1} \mathrm{Hb}\right)$} & Mean & $1,188.3$ & $1,505 \bullet$ & $1,338.3^{\star \star \star}$ & $1,308.3^{\star \star \star}$ & $1,298.3^{\star \star \star}$ & $1,313.3^{\star \star \star}$ & $1,306.7^{\star \star \star}$ & $1,328.3^{\star * \star}$ & $1,325^{\star \star \star}$ \\
\hline & $\pm S E$ & 22.531 & 18.962 & 29.930 & 20.192 & 16.898 & 19.527 & 17.102 & 16.227 & 20.192 \\
\hline & $\%$ Change & - & +27 & -11 & -13 & -14 & -13 & -13 & -12 & -12 \\
\hline \multirow[t]{3}{*}{$\mathrm{IL}_{2}\left(\mathrm{ng} \mathrm{m}^{-1}\right)$} & Mean & 62.8 & $106.8 \bullet$ & $91.2^{*}$ & $88.8^{*}$ & $88^{*}$ & $91.2^{* *}$ & $90.2^{* *}$ & $92^{*}$ & $90.7^{\star}$ \\
\hline & $\pm S E$ & 2.073 & 4.662 & 4.554 & 2.670 & 2.614 & 2.597 & 2.228 & 4.102 & 3.934 \\
\hline & $\%$ Change & - & +70 & -15 & -17 & -18 & -15 & -16 & -14 & -15 \\
\hline
\end{tabular}

Values significantly differ from normal control: $\bullet$ : $p<0.001$

Values significantly differ from arthritic control:

${ }^{*}: p<0.025,{ }^{* *}: p<0.005,{ }^{* * *}: p<0.001$ 
Table 7

Nutritional parameters of different experimental groups

\begin{tabular}{|c|c|c|c|c|c|c|c|c|c|c|}
\hline \multirow[b]{2}{*}{ Parameters } & \multicolumn{10}{|c|}{ Groups } \\
\hline & & $\begin{array}{l}\text { Normal } \\
\text { control }\end{array}$ & $\begin{array}{c}\text { Arthritic } \\
\text { control }\end{array}$ & $\begin{array}{l}\text { Date } \\
\text { extract }\end{array}$ & $\begin{array}{c}\text { Fenugreek } \\
\text { extract }\end{array}$ & $\begin{array}{c}\text { Date \& } \\
\text { Fenugreek } \\
\text { extract }\end{array}$ & Fish oil & $\begin{array}{c}\text { Fish oil \& } \\
\text { Date extract }\end{array}$ & $\begin{array}{c}\text { Primrose } \\
\text { oil }\end{array}$ & $\begin{array}{c}\text { Primrose } \\
\text { oil \& Date } \\
\text { extract }\end{array}$ \\
\hline \multirow[t]{2}{*}{ Initial body weight (g) } & Mean & 154.8 & 154.8 & 154.8 & 154.8 & 154.8 & 154.8 & 154.8 & 154.8 & 154.8 \\
\hline & \pm SE & 12.92 & 13.33 & 7.39 & 7.39 & 3.572 & 10.11 & 9.899 & 8.03 & 7.01 \\
\hline \multirow[t]{2}{*}{ Final body weight (g) } & Mean & 209.7 & 192.3 & 195.7 & 195.7 & 204 & 200.8 & 209.8 & 202.7 & 201 \\
\hline & \pm SE & 12.58 & 11.72 & 7.14 & 7.143 & 2.129 & 10.32 & 6.934 & 8.24 & 8.682 \\
\hline \multirow[t]{2}{*}{ Body weight gain (g) } & Mean & 54.8 & $37.5 \bullet$ & 40.8 & 40.8 & $49.2^{\star \star}$ & 46 & $55^{\star \star}$ & 47.8 & 46.2 \\
\hline & \pm SE & 3.46 & 2.93 & 2.76 & 2.761 & 2.441 & 6.026 & 5.149 & 5.223 & 4.452 \\
\hline \multirow[t]{2}{*}{ Total food intake (g) } & Mean & 486.5 & 507.1 & 492.5 & 492.5 & 493.3 & 493.7 & 471.4 & 512.5 & 484.8 \\
\hline & \pm SE & 23.91 & 18.09 & 5.92 & 5.917 & 11.122 & 9.83 & 12.909 & 5.699 & 16.768 \\
\hline \multirow[t]{2}{*}{ Food efficiency ratio } & Mean & 0.113 & $0.074 \bullet$ & 0.083 & 0.083 & $0.100^{\star \star *}$ & 0.093 & $0.117^{\star \star \star \star}$ & 0.094 & $0.095^{\star}$ \\
\hline & \pm SE & 0.005 & 0.006 & 0.009 & 0.004 & 0.004 & 0.011 & 0.008 & 0.01 & 0.007 \\
\hline
\end{tabular}

Values significantly differ from normal control: $\bullet: p<0.001$

Values significantly differ from arthritic control:

${ }^{*}: p<0.05,{ }^{* *}: p<0.010,{ }^{* * *}: p<0.005,{ }^{* * *}: p<0.001$

superoxide dismutase to provide additional protection, but conversely may lead to increased oxidative stress. The increased superoxide dismutase promotes the dismutation of superoxide ion into $\mathrm{H}_{2} \mathrm{O}_{2}$, which, if accumulated in the absence or reduction or even no increase in either glutathione peroxidase (which is the case in the present study) or catalase, may produce oxidative damage. This is because the superoxide dismutase antioxidant effect must be complemented by glutathione peroxidase and catalase dismutation of $\mathrm{H}_{2} \mathrm{O}_{2}$ into $\mathrm{H}_{2} \mathrm{O}$ otherwise superoxide dismutase may have an oxidant effect. It has been reported that increased superoxide dismutase is probably inadequate to exert antioxidant protection but can result in a pro-oxidant and pro-inflammatory pathogenic effect which enhances tissue damage and might be used as a marker of inflammatory activity in rheumatoid arthritis (Mazzetti et al., 1996). In a previous work no changes in erythrocyte catalase level were reported in rheumatoid arthritis patients when compared to the control (Gambhir et al., 1997). The changes in relative levels of antioxidants vis-à-vis free radical formation and level could be used as indicators for effective and earlier diagnosis of RA (Kalpakcioglu and Senel, 2008). IL2, a cytokine that reflects inflammatory conditions showed significant elevation in the adjuvant arthritic control in the present study. Reduced plasma zinc and elevated plasma copper in the adjuvant arthritic control in the present study agreed with the results of Rafe et al. (1994) and Quivy et al. (1995). In a previous study dealing with adjuvant arthritic rats, copper was reported to be significantly increased in plasma, blood, liver, spleen and arthritic paw, whereas, it was noticed to be lower than normal in the kidney. Zinc was remarkably increased in the liver but decreased in plasma and almost unchanged in the cellular fraction (Milanino et al., 1993).

Feeding the different functional foods produced a reduction in inflammation thickness and improvement in the biochemical parameters reflecting efficient functional activity towards adjuvant arthritis. The anti-inflammatory effect of the methanol extract of fenugreek and date might be due to their phenolic content, where date fruits contain gallic acid, ferulic acid, vanillic acid, caffeic, protocatechuic, p-hydroxybenzoic acid, p-coumaric and syrigic. Vitexin, vitexin glycoside, orientine and iso-orientin are present in fenugreek seeds. Phenolic compounds have multiple biological effects including antioxidant activity (Löliger, 1999), anti-inflammatory, antiallergic (Middleton and Kandaswami, 1993; Hanasaki et al., 1994) and vasodilatory actions (Maistro et al., 2011). In addition, some phenolic compounds inhibit lipid peroxidation, platelet aggregation, capillary permeability, and fragility and the activity of enzyme systems including cyclo-oxygenase and lipoxygenase (Middleton and Kandaswami, 1993, Naemura et al., 2005). Phenolic compounds may exert these effects through their antioxidants, free radical scavenging (Jayanthi \& Subash, 2010) and chelation of divalent cations (Dowling et al., 2010). In a previous work, plant food extract mixtures rich in phenolic compounds in addition to tocopherols and carotenoids showed beneficial therapeutic effects towards adjuvant arthritis in rats (Al-Okbi et al., 2011).

Fenugreek contains steroidal sapogenins, the most important of which are diosgenin, tiogenin, yamogenin, gitogenin and neotigogens (Petit et al., 1995), which may render fenugreek, extract an anti-inflammatory activity. 
The anti-inflammatory activity of primrose oil may be related to the presence of $\gamma$-linolenic acid and $\beta$-amyrine (Al-Okbi et al., 2000). $\gamma$-linolenic acid (in primrose oil) can be converted in the body by an elongase enzyme to dihomo- $\gamma$-linolenic acid that competes with arachidonic acid for oxidative enzymes thereby reducing cyclooxygenase products, which instead produce PGE1 that has anti-inflammatory and immuno-regulating properties. It also blocks the transformation of arachidonic acid to leukotrienes and reduces inflammation (Deluca et al., 1999). Tissue oxidative stress was reduced after supplementation of primrose oil which may be through a reduction in lipid peroxidation where the ratio of reduced glutathione: oxidized was increased (Dela-Cruz et al., 1999). The presence of long-chain $\omega 3$ polyunsaturated fatty acids (EPA and DHA) in fish oil is beneficial in the treatment of autoimmune and allergic inflammatory conditions including RA (Stamp et al., 2005; Calder, 2006). Increasing the amount of EPA in membrane phospholipids not only reduces the level of arachidonic acid (AA) available for metabolism by lipoxygenases and cyclooxygenases, but also competes with AA for metabolism to form metabolites of less proinflammatory than the AA derived metabolites, thereby taming the inflammatory reaction (Calder, 2006). Long chain fatty acids have been reported to have anti-denaturant activity that protects against protein denaturation, which might be beneficial in rheumatoid arthritis and other rheumatic conditions (Saso et al., 1999). This is may be another mechanism of action of primrose oil and fish oil due to their long chain fatty acid contents.

Some sorts of malnutrition have been reported in RA which is reflected by reduction in body weight gain and food efficiency ratio in the control arthritic rats in the present study which agreed with previous works (Al-Okbi et al., 2011; Abdel-Moein et al., 2011). Loss of lean tissues in RA and adjuvant arthritis might be the cause of the body weight reduction noticed in the present study. Lean tissue loss might be due to the acceleration rate of protease-mediated degradation of muscle protein without changes in protein synthesis in experimental arthritis. Intracellular proteolysis of muscle proteins by lysosomal proteases is mediated by $P \mathrm{FE}_{2}$, the later increased during inflammation. There is no doubt that improvement in body weight gain and food efficiency ratio after supplementation of the functional food as shown in the present study points to their therapeutic efficiency towards RA.

The results showed the stability of functional ingredients in jam during storage for 2 months at $4^{\circ} \mathrm{C}$. The stability of unsaturated fatty acids might be due to the presence of phenolic compounds in dates of the jam itself in the case of functional food that contain either fish oil or primrose oil without date or fenugreek extract. The stability of unsaturated fatty acids was better in the case of presence of the phenolic rich date extract since phenolic compounds produce antibacterial and antioxidant effects (Hanasaki et al., 1994: Jayanthi and Subash, 2010).

The ultimate judge for the acceptance of a food product is the consumer, who selects his/her food products by considering their sensory properties. In the present study, the sensory evaluation of the different functional foods showed satisfactory results.

In conclusion, all the tested functional foods showed promising anti-inflammatory effects and bioactivity towards adjuvant arthritis and were accepted through sensory evaluation, thus recommending their potential use as a beneficial dietary adjunct for rheumatoid arthritis patients.

\section{REFERENCES}

Abdel-Moein NM, Abdel-Moniem EA, Mohamed DA, Hanfy EA. 2011. Evaluation of the anti-inflammatory and anti-arthritic effects of some plant extracts. Grasas Aceites. 62, 365-374.

Abe A, Yamashita S, Noma A. 1989. Sensitive, direct colorimeteric assay of copper in serum Clin. Chem. 35, 552-4.

Al-Okbi SY, Ammar NM, Abdel-Samed AM, Rashed MM, Mohamed DA. 1998. Biochemical, nutritional and pharmacological evaluation of the anti-arthritic activity of some Egyptian plants. J. Drug Res. Egypt. 22, 321338.

Al-Okbi SY, Ammar NM, Mohamed DA. 1999. Assessment of the safety of use of certain natural anti-inflammatory agents and their effects on nutritional status in adult and growing rats. Med. J. Islam. Acad. Sci.12, 13-24.

Al-Okbi SY, Ammar NM, Soroor KhA, Mohammed DA. 2000. Impact of natural oils supplements on disease activity and antioxidant state of Egyptian patients with rheumatiod arthritis. Med. J. Islam. Acad. Sci. 13, 161- 171.

Al-Okbi SY, Mohamed DA, Donya SM and Abd El Khalek AB. 2011. Role of Bifidobacterium bifidum and Plant Food Extracts in Improving Microflora and Biochemical and Cytogenetic Parameters in Adjuvant Arthritis. Grasas Aceites. 62, 308-320.

Ammar NM, Al-Okbi, SY, Mohamed DA. 1997. Study of the anti-inflammatory activity of some medicinal edible plants growing in Egypt. J. Islam. Acad. Sci. 10, 113-122.

AOAC. 2000. Official Methods of Analysis. $17^{\text {th }}$ ed. Association of Official Analytical Chemists International, Arlington, Virginia, USA.

Arvidsson NG, Gudjornsson B, Hallgren R, Larsson A. 1998. Concordant message of different inflammatory markers in patients with rheumatoid arthritis. Upsala J. Med. Sci. 103, 35-42.

Brenol CV, Monticielo OA, Xavier RM, Brenol JC. 2007. Rheumatoid arthritis and atherosclerosis. Rev. Assoc. Med. Bras. 53, 465-70.

Calder PC. 2006. n-3 Polyunsaturated fatty acids, inflammation, and inflammatory diseases Am. J. Clin. Nutr. 83, 1505S -1519S.

Dela-Cruz JP, Quintero L, Gálvez J, Villalobos MA, Sánchez de la Cuesta F.1999. Antioxidant potential of evening primrose oil administration in hyperlipemic rabbits. Life Sci. 65, 543-555.

De Luca P, Rossetti RG, Alavian C, Karim P, Zurier RB. 1999. Effect of gamma-linolenic acid on interleukin- 
1B and tumor necrosis factor- secretion stimulated human peripheral blood monocytes: studies in vitro and in vivo. J. Invest. Med. 47, 247-250.

Dowling S, Regan F, Hughes H. 2010. The characterisation of structural and antioxidant properties of isoflavone metal chelates. J. Inorg. Biochem. 104, 1091-8.

Gambhir JK, Lali P, Jain AK. 1997. Correlation between blood antioxidant levels and lipid peroxidation in rheumatoid arthritis. Clin. Biochem. 30, 351-5.

Hanasaki Y, Ogawa S, Fukui S. 1994. The correlation between active oxygens scavenging and antioxidative effects of flavonoids. Free Radical Bio. Med. 16, 845850.

Homster R, Zak B. 1985. Determination of zinc in plasma. Clin. Chem. 31, 1310-1313.

Jayanthi R, Subash P. 2010. Antioxidant effect of caffeic Acid on oxytetracycline induced lipid peroxidation in albino rats. Indian J. Clin. Biochem. 25, 371-5.

Kalpakcioglu B, Senel K. 2008. The interrelation of glutathione reductase, catalase, glutathione peroxidase, superoxide dismutase, and glucose-6phosphate in the pathogenesis of rheumatoid arthritis. Clin. Rheumatol. 27, 141-5

Kiziltunc A, Cogalgil S, Cerrahoglu L. 1998. Carnitine and antioxidants levels in patients with rheumatoid arthritis. Scand. J. Rheumatol. 27, 441-5.

Löliger J.1999. The use of antioxidants in food. In Free radicals and food additives. Edited by O.I. Aruoma and B. Halliwell. Taylor and Francis, London. pp. 129.

Maistro EL, Angeli JP, Andrade SF, Mantovani MS. 2011. In vitro genotoxicity assessment of caffeic, cinnamic and ferulic acids. Genet. Mol. Res. 10, 1130-40.

Mazzetti I, Grigolo B, Borzi RM, Meliconi R, Facchini A. 1996. Serum copper/zinc superoxide dismutase levels in patients with rheumatoid arthritis. Int. J. Clin. Lab. Res. 26, 245-49.

Middleton E Jr, Kandaswami C. 1993. The impact of plant flavonoids on mammalian biology: Implications for immunity, inflammation and cancer. In the flavonoids: Advances in research since 1986. Edited by J.B. Harborne. Chapman and Hall, London, UK. pp. 619652.

Milanino R, Frigo A, Bambara LM, Marrella M, Moretti U, Pasqualicchio M, Biasi, D, Gasperini R, Mainenti L, Velo GP. 1993. Copper and zinc status in Rheumatoid arthritis: Studies of plasma, erythrocytes, and urine, and their relationship to disease activity markers and pharmacological treatmeant. Clin. Exp. Rheumatol. 11, 271-281.

Mohammed DA, Al-Okbi SY. 2004. In-vivo evaluation of anti-oxidant and anti-inflammatory activity of date fruits in adjuvant arthritis. Pol. J. Food Nutr. Sci. 13/54, 397-402

Mohammed DA, Al-Okbi SY. 2005. In vitro evaluation of antioxidant activity of different extracts of phoenix dactylifera L. fruits as functional foods. Deut. lebensm-Rundsch. 101, 305-308.

Mohamed DA, Hamed TE and Al-Okbi SY. 2010. Reduction in hypercholesterolemia and risk of cardiovascular diseases by mixtures of plant food extracts: a study on plasma lipid profile, oxidative stress and testosterone in rats. Grasas Aceites. 61, 378-389.
Naemura A, Mitani T, ljiri Y, Tamura Y, Yamashita T, Okimura M, Yamamoto J. 2005. Anti-thrombotic effect of strawberries. Blood Coagul. Fibrin. 16, 501-9.

Paglia DE, Valentine WN. 1967. Studies on the quantitative and qualitative characterization of erythrocyte glutathione peroxidase. J. Lab. Clin. Med. 70, 158-169.

Petit PR, Sauvaire YD, Hillaire-Buys DM, Leconte OM, Baissac YG, Ponsin GR, Ribes GR. 1995. Steroid saponins from fenugreek seeds: extraction, purification, and pharmacological investigation on feeding behavior and plasma cholesterol. Steroids. 60, 674-80.

Quivy D, Neve J, Fontaine J, Wasowicz W, Fomaey JP, Peretz A. 1995. Trace element status and inflammation parameters during chronic indomethacin treatment in adjuvant arthritis rats. Biol. Trace Elem. Res. 47, 209-18.

Rafe AM, Philcox JC, Haynes DR, Coyle P. 1994. Wasting in adjuvant-induced arthritis and its relationship to plasma zinc, copper and liver metallothionein. Agent Actions. 42, 60-62.

Ratheesh M, Shyni GL, Helen A. 2009. Methanolic extract of Ruta graveolens L. inhibits inflammation and oxidative stress in adjuvant induced model of arthritis in rats. Inflammopharmacology. 17, 100-5.

Roth EF, Gilgert HS. 1984. The pyrogallol assay for superoxide dismutase: absence of glutathione artifact. Anal. Biochem. 137, 50-3.

Saso L, Valentini G, Casini ML, Mattei E., Braghiroli L, Mazzanti G, Panzironi C, Grippa E, Silvestrini, B.1999. Inhibition of protein denaturation by fatty acids, bile salts and other natural substances: a new hypothesis for the mechanism of action of fish oil in rheumatic diseases. Jpn. J. Pharmacol. 79, 89-99.

Singh G B, Singh S, Bani S, Gupta B D, Banerje S K. 1992. Anti-inflammatory activity of oleanolic acid in rats and mice. J. Pharm. Pharmacol. 44, 456-458.

Singleton VL, Orthofer R, Lamuela-Raventos RM. 1999. Analysis of total phenols and other oxidants substrates and antioxidants by means of FolinCiocalteu reagent. Method. Enzymol. 229, 152-178.

Stamp LK, James MJ, Cleland LG. 2005. Diet and rheumatoid arthritis: a review of the literature. Semin. Arthritis Rheum. 35, 77-94.

Tuncer S, Kamanli A, Akcil E, Kavas GO, Seckin B, Atay MB. 1999. Trace element and magnesium levels and superoxide dismutase activity in rheumatoid arthritis. Biol. Trace Elem. Res. 68, 137-42.

Westergren A. 1921. Studies of the suspension stability of the blood in pulmonary tuberculosis. Acta Med. Scand. 54, 247-282.

Winyard PG, Ryan B, Eggleton P, Nissim A, Taylor E, Lo Faro, ML, Burkholz T, Szabó-Taylor KE, Fox $B$, Viner N, Haigh RC, Benjamin N, Jones AM, Whiteman M. 2011. Measurement and meaning of markers of reactive species of oxygen, nitrogen and sulfur in healthy human subjects and patients with inflammatory joint disease. Biochem. Soc. T. 39 , 1226-32.

Recibido: 26/12/11 Aceptado: 19/6/12 